DOI 10.18551/rjoas.2019-09.25

\title{
SWOT ANALYSIS AND RISK ASSESSMENT MATRIX ON GARLIC SEED FARMING IN KARANGANYAR
}

\author{
Noor Hana Fadhillah*, Kusnandar, Irianto Heru \\ Faculty of Agriculture, University of Sebelas Maret, Indonesia \\ ${ }^{\star}$ E-mail: hanafadhillah09@gmail.com
}

\begin{abstract}
Agriculture is a type of production activity which is based on the growth process of plants and animals. Farming is an organizational unity between work, capital and management that is shown to obtain production in agriculture. Farming to be more productive and efficient efforts must be made to manage and manage farming. Factors that influence farming can be classified into two things, namely internal and external factors of farming. SWOT analysis is the systematic identification of various factors to formulate a strategy. SWOT analysis is based on logic that can maximize strengths, opportunities, but can simultaneously minimize weaknesses and threats. SWOT is an abbreviation of internal factors, namely Strength and Weakness and external factors, namely opportunities and threats faced. SWOT analysis compares the external factors of opportunity and Threat with the internal factors of strengths and weaknesses. This study uses a SWOT Analysis and Risk Assessment Matrix and the risks are classified as critical. From the results of the study there are four risks to the farm that are classified as critical according to the risk assessment matrix results, namely Pests Attack on garlic seeds (9a), Diseases on garlic seeds (9b), Plants are too dense and many weeds (8a) and Plants are less fertile due to too much weed (8b). To reduce the level of risk and the level of failure in the process of farming garlic seeds, it is necessary to mitigate the risks of those classified as critical risks.
\end{abstract}

\section{KEY WORDS}

SWOT, risk, risk assessment matrix, risk identification, critical risk, garlic seed, farming.

Agriculture is a type of production activity that is based on the growth process of plants and animals (Soetriono, 2006). Farming is an organizational unity between work, capital and management that is shown to obtain production in agriculture. Farming to be more productive and efficient must be made efforts to manage and manage farming. Factors that affect farming can be classified into two things, namely internal and external factors in farming. Factors from internal farming include managing farmers (individual farmers), farm land, labor used in farming, the level of technology used in farming, the ability of farmers to allocate family income, and the number of family members. Factors from external farming include the availability of transportation and communication facilities, aspects relating to marketing of farm products and materials (yield price, input price, etc.), credit facilities, and extension facilities for farmers (Soetriono, 2006 ).

In farming a lot of risks occur that make losses to farming. Risk is a form of uncertainty about a situation that will occur later with decisions taken based on current considerations (Fahmi, 2013). Risk Management is a field of science that discusses how an organization applies measures in mapping various existing problems by placing various management approaches comprehensively and systematically (Fahmi, 2013). Although the risks are varied and certainly exist, the risks can be detected early so that the impacts that can be anticipated can be anticipated. Risk management so that the risk does not become a disruption in industrial activities is usually referred to as risk management. Therefore risk management to reduce and minimize losses is very important for small businesses considering the risks faced by small and medium industries are quite diverse (Sari, Yuniarti, and Puspita, 2017). In farming practice, despite having long experience in farming for agricultural commodities, farmers cannot always achieve the level of efficiency and productivity as expected. Even though they use the same technology package, even in the same season and on the same 
land, diversity always arises. This is caused by the results achieved are basically the resultant operation of so many factors, both those that can be controlled (internal) and factors that cannot be controlled (external) (Suharyanto, Rinaldy, and Arya, 2015). Strategic management consists of the analysis, decisions, and actions of an organization undertaking in order to create and sustain competitive advantages. The strategic management process is a sequential set of analyzes and choices that can increase the likelihood that an organization will choose 'good strategy', that is, that generates competitive advantages (Gurel, 2017). Production risk of production affects the production results and affects the income of garlic seed farming (Darmansyah, Muani, and Radian, 2017). Internal strengths or weaknesses, combined with external opportunities or threats and clear mission statements, form the basis for setting goals and strategies. The goals and strategies are set with the intention of utilizing internal strengths and overcoming weaknesses (Rosmiati, 2016).

SWOT analysis is the systematic identification of various factors to formulate a strategy. SWOT analysis is based on logic that maximizes strengths, opportunities, but simultaneously minimizes weaknesses and threats. SWOT is an abbreviation of the Internal Strength and Weakneses environment and the external environment of Opportunities and Threats encountered. SWOT analysis compares the external factors of opportunity and threats with the internal factors of strengths and weaknesses (Rangkuti, 2002). SWOT analysis may occur in achieving a goal of business or industrial activity on a broader scale (Hamelberg, Sutrisno, and Pikirsingon, 2017). The risk treatment step taken must fully consider internal elements (strengths and weaknesses) and external (opportunities and threats). This aims to implement the risk treatment steps to meet priority scale so that it does not affect the planning of activities in other fields (Bahari, Leksono, and Ismiyah, 2018). SWOT analysis is based on logic that can maximize strengths and opportunities which can simultaneously maximize weaknesses and threats (Hasan, Laapo, and Rauf, 2016). SWOT provides an organized basis for discussion and information sharing to improve managerial strategic decision making (Fattah, 2016).

Garlic is one of the most popular onion members in the world. Garlic is not only famous as a food seasoning, but also as an antidote to various diseases (Wibowo, 2009). The high demand for garlic is not matched by the availability of garlic in Indonesia. As a solution to overcome the lack of availability of garlic in Indonesia, the Government is importing garlic to meet domestic garlic needs. The quality of imported quality garlic and its large shape makes many consumers choose imported garlic. Much research is needed to produce quality garlic seeds so that Indonesia can be self-sufficient in garlic and does not need to import from other countries.

This study focuses on identifying risk management in garlic seed farming with a SWOT analysis. SWOT analysis is done by identifying the strengths and positive factors originating from internal organizations, weaknesses and negative factors from internal organizations, opportunities or opportunities and advantages of external factors and threats or risks (Fahmi, 2013). The purpose of this study was to determine the strategic management of the SWOT Analysis and identify critical risks in garlic seed farming in order to mitigate risks so as to minimize the loss of farmers. Risk assessment in SWOT analysis research on white bottom seed farming using risk matrix based on the level of probability (impact), severity and handling of these risks in relation to detection (controllability). From the results of this risk assessment, it can be seen which risks are the priorities that must be addressed and strategies can be made to reduce or minimize losses that will be borne by the garlic seed farming.

\section{METHODS OF RESEARCH}

The research location was in Kalisoro Village, Tawangmangu District, Karanganyar Regency, with 31 census farmers as farmers in the Taruna Tani Farmers Group. In this study, because the population is relatively small and relatively easy to reach, the authors use the total sampling method. With this sampling method it is expected that the results can tend to be closer to the true value and is expected to also minimize the occurrence of errors or 
deviations from the population value (Usman \& Akbar, 2008). This research was conducted with 31 farmers as a census, namely farmers from the farmers' group Taruna Tani with Mr. Bejo as Chairman of the Farmers Group. This type of research is a qualitative descriptive study conducted to identify internal and external factors in implementing the strategy of developing garlic seed farming. Descriptive analysis is done by describing and analyzing research data.

\section{RESULTS AND DISCUSSION}

Identify the risks that are classified as critical by SWOT Analysis. SWOT analysis is the systematic identification of various factors to formulate a company's strategy. This analysis is based on logic that can maximize strengths and opportunities, but simultaneously can minimize weaknesses and threats (Rangkuti, 2006). SWOT analysts can make Strength, Weakness, Opportunity and Threat (SWOT) analyzes. The SWOT analysis conducted is as follows:

\section{A. Strength}

Garlic seed farming has several strengths, namely:

1. Fertile soil conditions;

2. Supporting climatic conditions;

3. Support of Farmer Groups;

4. Entrepreneurial Experience;

5. Farming for generations;

6. Easy access to garlic seed sales;

7. Large farmers' land.

B. Weakness

Garlic seed farming has several weaknesses, namely:

1. Lack of mastery of technology;

2. Depending on the growing season;

3. Availability of farming production facilities such as fertilizers and pesticides;

4. Lack of knowledge of farmers in semi-organic farming;

5. Lack of farmer's capital for farming;

6. Lack of manpower to help farm farmers.

C. Opportunity

Garlic seed farming has several opportunities, namely:

1. High price of garlic seeds;

2. Request continuous garlic seeds;

3. Government policies support the self-sufficiency of garlic;

4. Financial institutions that support both banks and non-banks;

5. Agricultural Extension Support.

D. Threat

Garlic seed farming has two threats, namely:

1. Climate and weather are erratic;

2. Pests and plant diseases.

After the results of the SWOT analysis, the risk of garlic seed farming can be identified by looking at the Good Agriculture Practice (GAP) process in garlic seed farming. Risk assessment using a risk assessment matrix with calculation of the probability impact matrix with a comparison of the impact and probability on the risk of garlic seed farming. The risks contained in garlic seeds with Good Agriculture Practice (GAP) and there are 10 processes in garlic seed farming and there are 30 risks in 10 processes of Good Agriculture Practice (GAP). The risk assessment matrix is the result of severity and occurrence. Severity is the impact that arises when an error (failure) occurs. Occurrence is the likelihood or probability or frequency of errors. Following are the risks and severity $(\mathrm{S})$ and occurrence $(\mathrm{O})$ calculations.

Table 1 is the Severity $(S)$ and Occurrence $(O)$ Values table for determining risk priority areas using two values, namely severity values and occurrence values, while Table 2 is a table of risk assessment level. In Probability Impact Matrix assessment that uses two values, 
the average value of the severity value and the occurrence values are not even, then rounding is done.

Table 1 - Severity (S) and Occurrence (O) Values

\begin{tabular}{|c|c|c|c|c|}
\hline No. & Process & Process Component & Severity & Occurrence \\
\hline \multirow[t]{4}{*}{1.} & Location Selection & a. The soil is not loose enough & 2.6 & 2.6 \\
\hline & & b. Less humus soil & 2.9 & 2.5 \\
\hline & & c. The location is too steep & 3.5 & 3.3 \\
\hline & & d. Soil $p H$ is inappropriate $(6.0-6.8)$ & 3.9 & 3.6 \\
\hline \multirow[t]{4}{*}{2.} & Planting Time Determination & a. Uncertain climate and weather & 4.4 & 4.4 \\
\hline & & b. High rainfall & 4 & 4 \\
\hline & & $\begin{array}{l}\text { c. Environment temperature that is not suitable for } \\
\text { garlic }\end{array}$ & 3.7 & 3.2 \\
\hline & & d. There is an error on plant rolling calculation & 3.3 & 3.3 \\
\hline \multirow[t]{3}{*}{3.} & Land Setting up & a. Waterlogged soil & 2.4 & 2.2 \\
\hline & & $\begin{array}{l}\text { b. Soil pH is too acidic or wet, special treatment is } \\
\text { required }\end{array}$ & 3.7 & 3.3 \\
\hline & & c. Excessive plant weeds & 4.4 & 4.3 \\
\hline \multirow[t]{3}{*}{4.} & Seed Preparation & a. Cloves released from the skin (peeled off) & 2.4 & 2.4 \\
\hline & & b. Tuber size is not suitable & 2.4 & 2.4 \\
\hline & & c. Tubers have been separated into clove & 2.3 & 2.4 \\
\hline \multirow[t]{5}{*}{5.} & Planting and Basic Fertilization & a. Space setting is not appropriate & 3 & 2.7 \\
\hline & & b. Plant distance is too close & 2.7 & 2.8 \\
\hline & & $\begin{array}{l}\text { c. Soil is too acidic or wet, so special treatment is } \\
\text { needed }\end{array}$ & 3.9 & 3.7 \\
\hline & & d. The beds are not suitable (too long) & 3.1 & 2.9 \\
\hline & & e. When planting the soil is too dry & 3.6 & 3.5 \\
\hline \multirow[t]{3}{*}{6.} & Irrigation & a. Frequency of irrigation is too often & 2.6 & 2.7 \\
\hline & & b. The land is too muddy & 2.3 & 2.2 \\
\hline & & c. Uncertain rainfall & 4 & 3.6 \\
\hline 7. & Supplementary Fertilization & Lack of sulphur that affects the garlic aroma & 4 & 3.5 \\
\hline \multirow[t]{2}{*}{8.} & Weeding & a. The soil is too dense and a lot of plants weed & 4.6 & 4.4 \\
\hline & & $\begin{array}{l}\text { b. Plants are less fertile because there are too many } \\
\text { weeds }\end{array}$ & 4.8 & 4.5 \\
\hline \multirow[t]{2}{*}{9.} & Pest (OPT) control & a. Pest attack on garlic seeds & 5 & 5 \\
\hline & & b. Disease attack on garlic seeds & 4.8 & 4.6 \\
\hline \multirow[t]{4}{*}{10.} & Harvest and Post Harvest & a. Age has met but there is no sign of harvest seen & 2.5 & 2.4 \\
\hline & & b. The stem is too dry which causes the stem to break & 2.7 & 2.4 \\
\hline & & $\begin{array}{l}\text { c. The appearance of mushrooms and fungus during } \\
\text { storage }\end{array}$ & 3.1 & 2.7 \\
\hline & & d. Broken garlic seeds during storage & 2.9 & 2.7 \\
\hline
\end{tabular}

Table 2 - Risk Assessment Level Table

\begin{tabular}{|c|c|c|}
\hline Level & Impact & Probability \\
\hline Very low & $1-2$ & $1-2$ \\
\hline Low & 3 & 3 \\
\hline Medium & 4 & 4 \\
\hline High & $5-7$ & $5-7$ \\
\hline Very high & $8-10$ & $8-10$ \\
\hline
\end{tabular}

\begin{tabular}{|c|c|c|c|c|c|c|}
\hline \multirow{4}{*}{$\begin{array}{l}\frac{\lambda}{\overline{0}} \\
\frac{0}{\pi} \\
\text { 응 } \\
\text { ㅇ }\end{array}$} & $\begin{array}{l}\text { Very } \\
\text { High } \\
\text { High }\end{array}$ & & & & $9 a, 9 b$ & \\
\hline & Medium & & $2 c, 3 b, 5 e, 7$ & $\begin{array}{l}1 \mathrm{~d}, 2 \mathrm{a}, 2 \mathrm{~b} \\
3 \mathrm{c}, 5 \mathrm{c}, 6 \mathrm{c}\end{array}$ & $8 a, 8 b$ & \\
\hline & Low & $1 b, 10 b$ & $\begin{array}{c}1 \mathrm{a}, 1 \mathrm{c}, 2 \mathrm{~d} \\
5 \mathrm{a}, 5 \mathrm{~b}, 5 \mathrm{~d} \\
6 \mathrm{a}, 10 \mathrm{c}, 10 \mathrm{~d}\end{array}$ & & & \\
\hline & Very low & $\begin{array}{l}3 a, 4 a, 4 b \\
4 c, 6 b, 10 a\end{array}$ & & & & \\
\hline & & Very low & Low & Medium & High & Very high \\
\hline & & & & npact & & \\
\hline
\end{tabular}

Figure 1 - Matrix of Risk Assessment Results Note: Impact = Severity; Probability = Occurrence. 
Numbers are rounded up with a decimal value greater than $0.5(>0.5)$ and rounding down to a smaller decimal value equal to $0.5(\leq 0.5)$. Severity and occurrence values that range from 1 to 2 are rated as very low levels and value range 3 is categorized as low level. On figure 1 can be seen probability impact matrix assessment on the process of garlic seed farm.

On Figure 1, we can see matrix of risk assessment results by looking at the priority risk areas. In red areas and have a high impact with medium and high probability so that the results can be obtained. There are four critical risks in the process of garlic seeds farm. Four risks in farming that are classified as critical based on the value of severity and occurrence on probability impact matrix, are Pest attack on garlic seeds (9a), Disease attack on garlic seeds (9b), Plants too dense and lots of plant weeds (8a) and Plants are infertile due to too much weeds (8b). These four critical risks need to be mitigated by risk to reduce the failure rate or disability of garlic seeds.

\section{CONCLUSION}

In SWOT Analysis, strength of garlic seed farming is fertile soil conditions, favorable climatic conditions, support of farmer groups, farming experience, hereditary farming, easy access to sales of garlic seeds, large farmers' land. Garlic seed farming has several weaknesses, namely lack of technological mastery, depending on the growing season, the availability of farming production facilities such as fertilizers and pesticides, lack of knowledge of semi-organic farming farmers, lack of farmer capital for farming, lack of labor to help farmers farming. Garlic seed farming has several opportunities, namely the high price of garlic seeds, the continued demand for garlic seeds, government policies supporting garlic self-sufficiency, financial institutions that support both banks and non-banks, agricultural extension support. Garlic seed farming has two threats namely climate and erratic weather and pests and plant diseases. From the matrix of risk assessment results, it can be obtained items of farming processes that have a relatively critical level of risk. There are four risks to farming that are classified as critical according to the risk assessment matrix results, namely Pests Attack on garlic seeds (9a), Disease attacks on garlic seeds (9b), Plants are too dense and many plant weeds (8a) and Plants are less fertile because they are too lots of weeds (8b).

\section{REFERENCES}

1. Bahari, H., Leksono, E.B., Ismiyah, E., 2018. Pendekatan Risk Management and Analisis SWOT untuk Mengatisipasi Penurunan Laba di ECOS Minimarket Gresik. Jurnal Matrik Volume XVIII No.2, Maret 2018, p 23-40. doi: 10.350587/Matrik v18i2.585

2. Darmansyah,E., Muani,A, and Radian, 2017. Analisis Risiko Produksi Usahatani Jeruk Siam Pontianak (Citrus Nobilis Var. Microcarpa) Di Kabupaten Sambas. Jurnal Social Economic of Agriculture, Volume 6, Nomor 1, April 2017

3. Fahmi, I. (2013). Manajemen Risiko Teori, Kasus and Solusi. Bandung: Alfabeta.

4. Fattah, Nanang. 2016. Manajemen Strategik Berbasis Nilai. Bandung. PT Remaja Rosdakarya Offset

5. Gurel, Emet. 2017. SWOT Analysis A Theorical Review. The Journal of International Social Research Cilt: 10 Sayı: 51 Volume: 10 Issue: 51. Doi Number: http://dx.doi.org/10.17719/jisr.2017.1832

6. Hasan, H., Laapo, A., Rauf, R.A., 2016. Analisis Pendapatan and Strategi Pengembangan Usahatani Jagung Hibrida di Kecamatan Labuan Kabupaten Donggala. Jurnal. Agroland 23 (2): 26 - 39, April 2016

7. Hamelberg, J.Y, Sutrisno,A., and Punuhsingon,C., 2017. Penentuan Risiko Kritis Pada Distribusi Gas Dengan Menggunakan Integrasi Metode Ahp, Risk Management and analisis Swot. Jurnal Online Poros Teknik Mesin Volume 6 Nomor 2

8. Rangkuti, Freddy. 2006. Analisis SWOT Teknik Membedah Kasus Bisnis. Jakarta. PT Gramedia Pustaka Utama 
9. Rosmiati, Mia. 2016. Penerapan Analisa Swot Dalam Perencanaan Strategis Si/Ti Pada Ajb Bumi Putera Kantor Wilayah Cibinong. Jurnal Techno Nusa Mandiri Vol. XIII, No. 1 Maret 2016

10. Sari, R.A., Yuniarti, Ratih, Puspita, D.A., 2017. Analisa Manajemen Risiko pada Industri Kecil Rotan di Kota Malang. Journal of Industrial Engineering Management JIEM Vol.2 No. 2, Desember 2017

11. Suharyanto, Rinaldy, J., Arya, N.N, 2015. Analisis Risiko Produksi Usahatani Padi Sawah di Provinsi Bali. Jurnal Agraris Vol.1 No.2 Juli 2015. DOI:10.18196/agr.1210

12. Usman Husaini, \& Setiady, P. (2008). Metodologi Penelitian Sosial. Jakarta: PT. Bumi Aksara.

13. Wibowo. (2009). Budidaya Bawang. Jakarta: Penebar Swadaya. 